\title{
Tutkivaa oppimista oppivan organisaation hengessä
}

Henna Heinilä, Pekka Kalli \& Kaarina Ranne (toim.) (2009). Tutkiva oppiminen ja pedagoginen asiantuntijuus. OKKA-säätiö. Tampereen Ammattikorkeakoulu, Ammatillinen Opettajakorkeakoulu.

T utkiva oppiminen on Suomessa ongelmaperustaisen oppimisen ohella ehkä laajimmin huomiota saanut ja yhteisöllistä oppimista korostavaan oppimiskäsitykseen perustuva pedagoginen malli ja ajattelutapa. Malli on sikäli huomionarvioinen, että sitä sovelletaan hyvin erilaisilla oppimisen kentillä kasvokkain ja verkossa, sekä koulutuksen asteilla varhaiskasvatuksesta aikuiskasvatukseen. Siitä on vähitellen muotoutunut myös sosiokonstruktivistisen opetusoppimisparadigman eräänlainen tavaramerkki, jonka varaan on monia opetuksen kehittämiseen tähtääviä hankkeita lähdetty rakentamaan. Tämä on helppo ymmärtää, sillä mallille on myös osoitettavissa selkeät "oppihistorialliset" taustansa sosiokognitiivisten, tiedonluomista korostavien oppijalähtöisten ja tämän ajan tarpeisiin hyvin istuvien näkemysten parista. Se siis edustaa tietyllä tavalla valtavirtaa tämän hetken kotimaisella oppimisajattelun ja -tutkimuksen kentällä. Tämä valtavirtaisuus voi olla sekä eduksi että haitaksi, sillä joskus valtavirtaistuminen tuottaa myös hyvin normatiivisia toimintatapoja - eräänlaisia 'näin pitää tehdä' -tyyppisiä kaavamaisuuksia - jotka eivät luonnollisesti kaikkiin tilanteisiin päde yhtä hyvin.

Käsillä olevassa tutkivan oppimisen ja pedagogisen asian- tuntijuuden kirjassa sovelluskohteeksi kirjaa lukiessa paljastuu kuitenkin hieman laajempi konteksti - pedagogisen asiantuntijuuden kehittäminen ammatillisen opettajakorkeakoulun yksikössä-jossa kirjoittajat ovat olleet mukana muutaman vuoden kestäneen kehittämishankkeen toimijoina. Kirjoittajakunnassa on sekä entisiä opettajaksi opiskelleita että yksikön henkilökuntaan kuuluvia. Kyse näyttää siis olevan yhteisön moniulotteisesta kehittämisestä ja kehittymisestä oppivan organisaation suuntaan (s. 7). Sen verran laajalla kentällä kuitenkin toimitaan, että kirjan artikkeleiden tarkempi fokus jää välillä hieman hämäräksi: kehitetäänkö enemmän yhteisön omaa tulkintaa tutkivan oppimisen pedagogiikasta vai kehitetäänkö sittenkin yhteisön omia käytänteitä asiantuntijuutta jakavaan suuntaan oppivan organisaation hengessä? Kaarina Ranteen kirjoittama prologi antaisi aiheen odottaa jälkimmäistä, mutta monet kirjan artikkeleista kuitenkin liikkuvat enemmän edellisen, tutkivan oppimisen tulkinnan ja käsitteellistämisen, parissa.

Se mikä eniten kirjan artikkeleissa herättää ajatuksia, kriittisiäkin sellaisia, on kehittämistoimintaan hiipinyt sanasto. Sanasto ei ole aina lähtökohdiltaan puhtaan pedagogista, vaan työelämän kehittämisen kieleksi muotoutunutta osaamis- ja innovaatiopuhetta, jossa ehkä on tietynlainen tehokkuuteen liiketaloudelliseen ajatteluun perustuva leimansa. Luovuuden sijasta puhutaan mieluummin innovaatioista ja innovatiivisuudesta, joka on ehkä ideoiden markkinoinnin kannalta myyvempää (ks. Tenhusen, Siltalan ja Keskinen artikkeli). Anu Tenhunen, Reijo Siltala ja Soili Keskinen pyrkivät neutraloimaan tarkastelunsa käymällä läpi joukon kasvatustieteellisiä tutkimusartikkeleita ja toteuttamalla itsekin surveyn joukolle opettajia perusasteelta korkea-asteelle ja opettajaksi opiskeleville. He päätyvät tarkastelemaan kysymystä, mikä opetuksessa ehkä on innovatiivista ja millaista innovatiivinen opetus oikein on. Vaikka kyselyn tulokset ovatkin järkeenkäypiä, jää ilmaan edelleen väreilemään kysymys: miksei yhtä hyvin olisi luova opetus kelvannut kyselyn aiheeksi? Luovuuden keskiöön ihminen on ajatuksellisesti helpompi sijoittaa kuin innovaatioiden.

Innovaatioiden lisäksi silmään tarttuu myös johtamisen käsite, joka esimerkiksi Kaarina Ranteen omassa artikkelissa on otettu opettajan roolia ryhmäprosessin tukijana käsitteleväksi tarkastelukulmaksi. Tässä on mahdollisesti pyritty tekemään irtiottoa ohjaamisen näkökulmaan, sillä Ranne määrittelee (s. 43) pedagogisen ohjaamisen ja ryhmän johtamisen toisiaan täydentäviksi, mutta erilaisiksi, opettajan kompetenssialueeksi. Tämäkin liittyy tietyllä tavalla jat- 
koksi edellä mainittuun osaamisja innovaatiosanastoon ja siitä kumpuaviin osaamisen johtamisen näkökulmiin. Nyt on nähtävästi pyritty tarkastelemaan ohjaamisen ja vastuun jaettua prosessia oppimisryhmien itsensä ja ryhmän "johtajana" toimineen opettajan välillä, mikä sinänsä on kiinnostava teema. Mutta johtamisen käsitteen kohdalla helposti kuitenkin käy niin, että näkökulma pelkistyy ryhmän hallinnan ja tarkkailun muodollisiin puoliin, joten lukijana jää kuitenkin kaipaamaan pedagogis-ohjauksellista käsitteistöä kuvaamaan ryhmädynamiikan huomioimista ja työskentelyprosessien syventämistä opettajan taholta.

Artikkeleissa on myös paljon kuvauksia tutkivan oppimisen kokemuksista eri näkökulmista hankkeen aikana: verkko-opinnoista (Myllylä, Mäkelä \& Torp), tunteiden roolista (Heinilä), kokemuksellisuudesta ja reflektiosta (Harju \& Kumpulainen) sekä yrittäjyyskoulutuksesta (Kainu \& Nokkonen). Artikkeleissa on paljon omakohtaisia havaintoja ja reflektiota oppimiskokemuksista, erityisesti onnistuneista.

Enemmän olisi voinut tuoda esille myös koettua vaikeuksia ja mahdollisia ristiriitoja, sillä ne saattavat tuoda lukijan lähemmäksi kehittämistoiminnan autenttisia prosesseja ja antaa tarttumapintoja pohtia mahdollisia kriittisiä kohtia ja sovelluskohteita nyt esiteltyä kehittämistoimintaa laajemminkin. Henna Heinilän emotionaalisuutta käsittelevä artikkeli tuo joka tapauksessa tutkivan oppimisen sanastoon raikkaita uusia tuulia, sillä oppimiseen liittyvä käsitteistö on normaalisti hyvin kognitiivispainotteista. Samoin Teija Harjun ja Pasi Kumpulaisen kokemuksia ja reflektiota tarkasteleva artikkeli tuo tutkivan oppimiseen jopa aikuispedagogisia lisäaineksia, sillä he marssittavat mukaan muun muassa omien kokemusten ja sosiaalisesti jaettujen kokemusten merkityksen osana inhimillistä olemista ja elämänprojektia. Nämä mainitut kaksi artikkelia ehkä osuvat parhaimmin hankkeessa tehdyn tutkivan oppimisen organisaatiokohtaisen tulkinnan ja sanoittamisen pedagogiseen ytimeen.

Tutkivan oppimisen organisaatiokohtaisessa soveltamisessa väistämättä joudutaan miettimään myös koko oppilaitoksen tasolla tapahtuvaan prosessin kehittämistä, missä mukaan astuvat muun muassa opetussuunnitelmat ja arviointi. Oman huomionsa kirjassa (ja todennäköisesti hankkeessakin) on siten saanut arviointi. Pekka Kallin ja Henna Heinilän "kakkosartikkelit" hahmottavat arvioinnin problematiikkaa niin hankkeessa mukana olleiden opettajien ja opettajaopiskelijoiden arviointiajattelun kehittymisen että arviointikäytäntöjen muuntumisen kautta. Arviointi tutkivan oppimisen kontekstissa onkin liian harvoin ollut esillä. Arviointitarkastelu on myös vienyt kirjan fokusta takaisin prologissa esille nostetun yhteisön omien käytänteiden kehittämisen ja jakamisen suuntaan, mikä tekee näistä arviointiartikkeleista kokonaiskuvan kannalta avartavampia.

Tietyistä painotusvalinnoistaan ja "sanoitusongelmistaan" huolimatta kirja on melko mielenkiintoinen kokonaisuus, ainakin jos lukijaa kiinnostavana näkökulmana on tutkivan oppimisen organisaatiokohtainen soveltaminen ja tämän puitteissa tapahtuva omien käytänteiden kehittäminen. Kirjan merkitys ja tärkein anti onkin ehkä juuri tässä oppivan organisaation kertomuksessa, millainen kertomus koko oppilaitoksen siirtymisestä tutkivaan oppimiseen syntyy: uskalletaanko opettajana olemisen tapoja ja mahdollisuuksia lähteä yhdessä haastamaan ja uudelleen luomaan oppimisen ja opettamisen kulttuurisia malleja. Täytyy vain toivoa, että muuallakin uskalletaan.

\section{Vesa Korhonen}

\section{Myös nämä ovat ilmestyneet}

- Taina Joutsenvirta \& Arja Kukkonen (toim.) (2009). Sulautuva opetus - uusi tapa opiskella ja opettaa. Palmenia.

- Erja Vitikka (2009). Opetussuunitelman mallin jäsennys: sisältö ja pedagogiikka kokonaisuuden rakentajana. Akateeminen väitöskirja. Väitös 4.9.2009. Suomen Kasvatustieteellinen Seura.

- Arto Kallioniemi, Auli Toom, Martin Ubani, Helena Linnansaari \& Kristiina Kumpulainen (toim.) (2008). Ihmistä kasvattamassa. Koulutus - Arvot - Uudet avaukset. Hannele Niemen juhlakirja. Suomen Kasvatustieteellinen Seura. 